\title{
Onvrijwillige aansprakelijkheid van een moedervennootschap: een overzicht van de risico's en suggesties ter beperking daarvan
}

\author{
$M r . D . R . C . S m i t^{*}$
}

\begin{abstract}
Doorbraak van aansprakelijkheid is een risico voor de moedervennootschap van een concern. Aan de hand van arresten van de Hoge Raad brengt deze bijdrage de aansprakelijkheidsrisico's voor een moedervennootschap op grond van onrechtmatige daad jegens crediteuren van haar groepsvennootschap in kaart en reikt voorts suggesties aan ter beperking van die risico's.
\end{abstract}

\section{Inleiding}

In de concernfinancieringspraktijk komt het vaak voor dat de financier die een krediet verstrekt aan een groepsvennootschap zekerheid bedingt bij de moedervennootschap. Daarbij kan worden gedacht aan zakelijke zekerheidsrechten zoals pand en hypotheek, maar ook aan een persoonlijke zekerheid zoals borgtocht. Een hoofdelijke aansprakelijkheidsstelling voor uit rechtshandelingen voortvloeiende schulden via een 403-verklaring ${ }^{1}$ komt ook veelvuldig voor in de praktijk. Hoewel vaak sprake zal zijn van dergelijke zekerheden waarmee de moedervennootschap zich 'vrijwillig' aansprakelijk stelt, zal dat niet steeds het geval zijn. Banken zullen in ieder geval zekerheid (zowel zakelijke als persoonlijke zekerheden) hebben. Het gaat hierna dan ook vooral om de verhaalspositie van handelscrediteuren, en - in mindere mate - om banken voor zover hun vordering hetgeen door zekerheid wordt gedekt, overstijgt, en klanten die vooruit hebben betaald voor een dienst. Het probleem voor handelscrediteuren wordt vergroot door het feit dat banken zich veelal met voorrang

\footnotetext{
Mr. D.R.C. Smit is recent afgestudeerd aan de Universiteit Utrecht en binnenkort werkzaam bij Houthoff te Amsterdam.

1. Zie art. 2:403 lid 1 onder $\mathrm{fBW}$. Een 403-verklaring houdt in dat een consoliderende vennootschap (moedervennootschap) schriftelijk verklaart aansprakelijk te zijn voor schulden uit rechtshandelingen van een groepsvennootschap. Deze verklaring moet worden gedeponeerd bij het handelsregister (art. 2:403 lid 1 onder g BW). Hierdoor is de 403-groepsvennootschap vrijgesteld van publicatie en inrichting van haar jaarrekening conform titel 9 Boek 2 BW, mits ook aan de overige voorwaarden uit art. 2:403 BW wordt voldaan. Zie ook S.M. Bartman, A.F.M. Dorresteijn \& M. Olaerts, Van het concern, Deventer: Wolters Kluwer 2016, p. 195.
}

verhalen, waardoor er weinig overblijft voor de crediteur om verhaal op te nemen. ${ }^{2}$

Een crediteur zal bij wanbetaling van de groepsvennootschap alsnog - niettegenstaande de afwezigheid van voornoemde zekerheden en zijn mogelijk zwakke verhaalspositie - proberen verhaal te nemen op de moedervennootschap. Deze claim is normaal gesproken gebaseerd op een onrechtmatige daad van de moedervennootschap jegens de crediteur van de groepsvennootschap. Dit is een buitencontractuele aansprakelijkheid en bovendien heeft de moedervennootschap niet vooraf verklaard aansprakelijkheid op zich te willen nemen. Door een bepaald handelen of nalaten kan de moedervennootschap desalniettemin aansprakelijk zijn voor de schade die is ontstaan door het handelen van andere concernvennootschappen en de invloed die zij op dat handelen heeft gehad. Dit staat bekend als de doorbraak van aansprakelijkheid. ${ }^{3}$ De grondslag voor de ansprakelijkheid voor de schulden van de groepsvennootschap is een eigen onrechtmatige daad van de moeder jegens de crediteuren van de groepsvennootschap in de vorm van een schending van haar zorgplicht.

2. Een andere reden dat handelscrediteuren vaak moeilijker verhaal kunnen nemen, is dat verschillende partijen met voorrang verhaal kunnen nemen. Zo neemt het Uitvoeringsinstituut Werknemersverzekeringen (UWV) de loonvorderingen van werknemers van de failliete vennootschap over op grond van art. 66 WW. Dit is wettelijk verplicht bij een faillissement. Loonvorderingen van werknemers zijn bevoorrecht op grond van art. 3:288 onder e BW. Het UWV kan dus met voorrang verhaal nemen. Een ander voorbeeld is het voorrecht van de fiscus (zie art. 21 Invorderingswet 1990).

3. Deze figuur kent zowel een directe als een indirecte vorm. Bij de directe vorm is sprake van vereenzelviging: het terzijde stellen van het identiteitsverschil tussen, in dit geval, de moeder- en concernvennootschap. Een daartoe strekkende vordering wordt zelden gehonoreerd en wordt in deze bijdrage niet besproken. Zie in dit verband HR 13 oktober 2000, ECLI:NL:HR:2000:AA7480, NJ 2000/698 m.nt. Maeijer (Rainbow/ Ontvanger); en het meer recente arrest HR 7 oktober 2016, ECLI:NL:HR:2016:2285, NJ 2017/124 m.nt. Van Schilfgaarde (Resort of the World/Maple Leaf). In deze bijdrage gaat het uitsluitend om de indirecte vorm. 


\section{Maandblad}

Ondernemingsrecht

Deze bijdrage bespreekt de risico's van deze 'onvrijwillige' aansprakelijkheid die een moedervennootschap in haar hoedanigheid als aandeelhouder op basis van haar gedragingen kan lopen aan de hand van jurisprudentie van de Hoge Raad. Daarbij zal grotendeels worden geabstraheerd van de specifieke feiten van de betreffende casus, omdat het in deze bijdrage gaat om het identificeren van de risico's als zodanig voor een moedervennootschap. De rechtsregels (voor zover die door de Hoge Raad worden gegeven) zijn in dat kader relevanter dan de feiten.

De grondslag voor aansprakelijkheid van de moedervennootschap in haar hoedanigheid als aandeelhouder voor schulden van de groepsvennootschap(pen) is een eigen onrechtmatige daad in de zin van artikel 6:162 BW van de moeder jegens een schuldeiser van de groepsvennootschap. Dit leerstuk vindt zijn oorsprong in het Osby-arrest uit 1981 en is in de jurisprudentie de afgelopen vier decennia verder ontwikkeld. ${ }^{4}$ In dit arrest heeft de Hoge Raad geoordeeld dat onder omstandigheden een moedervennootschap aansprakelijk kan zijn op grond van een eigen onrechtmatige daad in de zin van artikel 6:162 BW jegens de schuldeiser(s) van haar groepsvennootschap. Ik onderscheid drie omstandigheden die kunnen bijdragen aan het vaststellen van een dergelijke onrechtmatige daad. Ten eerste is van belang de mate waarin de moeder zeggenschap heeft over het beleid van de groepsvennootschap en het inzicht dat dit de moeder oplevert, ten tweede de geobjectiveerde wetenschap bij de moeder van benadeling van de crediteuren van de groepsvennootschap, en ten slotte de schending van de zorgplicht van de moeder jegens de crediteuren van de groepsvennootschap.

In meer algemene zin geldt dat de groepsvennootschap als zelfstandig rechtssubject in beginsel uitsluitend zelf aansprakelijk is voor haar schulden. Voor de aansprakelijkheid van de moedervennootschap voor die schuld op grond van artikel 6:162 BW moet de moeder zelf een zorgvuldigheidsnorm hebben geschonden die zij jegens de schuldeisers van de groepsvennootschap in acht had behoren te nemen. ${ }^{6}$ Lennarts stelt in haar dissertatie dat een dergelijke zorgplicht van de moedervennootschap op twee manieren kan ontstaan: door (een verregaande) beleidsbemoeienis, in de hoedanigheid van (quasi)bestuurder, of door een hecht concernverband met de groepsvennootschap, in de hoedanigheid van aandeelhouder. ${ }^{7}$ In deze bijdrage gaat het uitsluitend om aansprakelijkheid

4. HR 25 september 1981, ECLI:NL:HR:1981:AG4232, NJ 1982/443 m.nt. Maeijer (Osby).

5. HR 25 september 1981, ECLI:NL:HR:1981:AG4232, NJ 1982/443 m.nt. Maeijer (Osby), r.o. 18, onderdeel 2.

6. Asser/Maeijer, Van Solinge \& Nieuwe Weme 2-II* 2009/839; M.L Lennarts, Onrechtmatige daadaansprakelijkheid van de moedervennootschap jegens schuldeisers van haar failliete dochter, FIP 2010, afl. 7, p. 188.

7. M.L. Lennarts, Concernaansprakelijkheid (diss. Groningen), Deventer: Kluwer 1999, p. 185 e.v. van de moedervennootschap in haar hoedanigheid als aandeelhouder. ${ }^{8}$

Hierna wordt in paragraaf $2 \mathrm{t} / \mathrm{m} 4$ besproken welk soort betrokkenheid en welke gedragingen van een moedervennootschap in haar hoedanigheid als aandeelhouder kunnen leiden tot een schending van die zorgplicht en daarmee tot aansprakelijkheid uit onrechtmatige daad. Om in het ogenschijnlijk grote aantal Hoge Raad-arresten en de daarin voorkomende gevallen enige orde aan te brengen, zullen de verschillende gedragingen van een moedervennootschap in twee categorieën worden verdeeld: enerzijds beleidsbemoeienis (in par. 2) en anderzijds het scheppen van te positieve, onjuiste verwachtingen (in par. 3). Binnen de eerste categorie, beleidsbemoeienis, worden drie subcategorieën onderscheiden:

1. voortzetten van verliesgevende activiteiten;

2. selectief betalen crediteuren; en

3. ongeoorloofd vermogen onttrekken aan groepsvennootschap.

Binnen de tweede categorie, het scheppen van te positieve verwachtingen, worden twee subcategorieën onderscheiden:

1. het wekken van een schijn van kredietwaardigheid; en

2. het niet nakomen van toezeggingen en het schenden van vertrouwen.

Mede aan de hand van de besproken aansprakelijkheidsrisico's wordt in paragraaf 4 een kort stappenplan gegeven voor de vaststelling van aansprakelijkheid van de moedervennootschap. Op basis van de geïdentificeerde risico's zal ik tot slot in paragraaf 5 enkele suggesties doen ter beperking van het aansprakelijkheidsrisico. Het gaat daarbij vooral om de bevoegdheidsband die bestaat tussen de moedervennootschap en haar groepsvennootschap(pen). Opmerking verdient dat deze suggesties ook negatieve aspecten kennen. Vanuit het oogpunt van concernleiding kan het onwenselijk zijn om minder bevoegdheden te hebben. Dit is dan ook een afweging die elke onderneming zelf dient te maken. Deze bijdrage biedt daarom primair een overzicht van de verschillende aansprakelijkheidsrisico's voor een moedervennootschap en probeert daarnaast verschillende manieren aan te reiken om die risico's te beperken.

\section{Beleidsbemoeienis}

De eerste categorie van gedragingen die aanleiding kunnen geven tot moederaansprakelijkheid bestaat uit beleidsbemoeienis van de moedervennootschap bij de groepsvennootschap. Dit kan bijvoorbeeld door het voortzetten van verliesgevende

8. Zie voor het onderscheid tussen aansprakelijkheid van de moedervennootschap als feitelijk beleidsbepaler en als aandeelhouder hierna ook par. 2 . 
activiteiten, ${ }^{9}$ het selectief betalen van crediteuren, ${ }^{10}$ of het ongeoorloofd vermogen onttrekken aan de groepsvennootschap, bijvoorbeeld door middel van een dividenduitkering. ${ }^{11}$ Deze situaties behandel ik hierna afzonderlijk.

Aangezien het in deze bijdrage uitsluitend gaat om moederaansprakelijkheid (aansprakelijkheid van de moedervennootschap in haar hoedanigheid als (indirect) aandeelhouder) op grond van artikel 6:162 BW, bespreek ik hierna niet de wettelijke aansprakelijkheidsgrond van artikel 2:138/248 lid 7 BW voor de moedervennootschap als feitelijk beleidsbepaler. $^{12}$

\subsection{Voortzetten van verliesgevende activiteiten}

In het arrest Sobi/Hurks II heeft de Hoge Raad overwogen dat een moedervennootschap onder omstandigheden de zorgplicht heeft om te voorkomen dat er op haar groepsvennootschap nieuwe vorderingen van crediteuren ontstaan, als de moeder weet of behoort te weten dat de groepsvennootschap die vorderingen niet kan voldoen. ${ }^{13}$ Bovendien moet de moedervennootschap ervoor zorgen dat crediteuren van de groepsvennootschap gewaarschuwd worden voor de penibele situatie waarin de groepsvennootschap verkeert. Deze zorgplicht van de moedervennootschap kan ontstaan op basis van de gehanteerde concernstructuur en de financieringsstructuur. ${ }^{14}$ In het geval van Sobi/Hurks II was de groepsvennootschap in grote mate afhankelijk van de moedervennootschap. Dit blijkt bijvoorbeeld uit de omstandigheid dat statutair was vastgelegd

9. HR 21 december 2001, ECLI:NL:HR:2001:AD4499, NJ 2005/96 m.nt. Kortmann (Sobi/Hurks II); HR 19 februari 1988, ECLI:NL:HR: 1988:AG5761, NJ 1988/487 m.nt. Van der Grinten (Albada Jelgersma II).

10. HR 12 juni 1998, ECLI:NL:HR:1998:ZC2669, NJ 1998/727 m.nt. Van Schilfgaarde (Coral/Stalt).

11. HR 8 november 1991, ECLI:NL:HR:1991:ZC0401, NJ 1992/174 m.nt. Maeijer (Nimox).

12. Het is echter wel mogelijk om een moedervennootschap als feitelijk beleidsbepaler aan te spreken via de weg van art. 6:162 BW. Zie bijv. HR 23 mei 2014, ECLI:NL:HR:2014:1204, NJ 2014/325 m.nt. Van Schilfgaarde. Zie voor het verschil tussen het aanspreken van een aandeelhouder-bestuurder op grond van bestuurdersaansprakelijkheid en een indirecte doorbraak van aansprakelijkheid E.C.H.J. Lokin \& O.J.W. Schotel, Aansprakelijkheidsrisico's bij het gebruiken van een lege projectvennootschap: aandeelhouders- of bestuurdersaansprakelijkheid?, MvO 2017, afl. 5-6, p. 141-152.

13. HR 21 december 2001, ECLI:NL:HR:2001:AD4499, NJ 2005/96 m.nt. Kortmann (Sobi/Hurks II); F. van Liere, De reikwijdte van de zorgplicht binnen concernverhoudingen, O\&F 2015, afl. 3, p. 52. Zie in dit verband ook het meer recente arrest HR 11 september 2009, ECLI:NL:HR: 2009:BH4033, NJ 2009/565 m.nt. Van Schilfgaarde (Comsys), waarin de Hoge Raad oordeelt dat een concernstructuur waarbij de kosten en opbrengsten worden opgesplitst, dusdanig inherent risicovol is, dat de moedervennootschap reeds bij het opzetten van deze concernstructuur al haar zorgplicht jegens crediteuren heeft geschonden. Het Comsys-arrest is dus relevant bij de bepaling van het peilmoment voor het ontstaan van de zorgplicht van de moedervennootschap jegens crediteuren van de groepsvennootschap, namelijk het moment waarop de concernstructuur in de praktijk wordt benut. Vgl. HR 19 april 2019, ECLI:NL:HR: 2019:640, JOR 2019/244 m.nt. Bartman en concl. A-G Hartlief, ECLI:NL:PHR:2019:138

14. HR 21 december 2001, ECLI:NL:HR:2001:AD4499, NJ 2005/96 m.nt. Kortmann (Sobi/Hurks II), r.o. 5.3.2-5.3.3. dat bepaalde bestuursbesluiten van de groepsvennootschap goedkeuring behoeven van de algemene vergadering (AV) (lees: de moedervennootschap in haar hoedanigheid als aandeelhouder), dat de moedervennootschap het centrale kasbeheer voert van de groep, en dat de groepsvennootschap ook hoofdelijk verbonden is voor schulden van het concern. ${ }^{15}$

De Hoge Raad heeft in Sobi/Hurks II de rechtsregel geformuleerd dat moedervennootschappen actief toezicht moeten houden op hun groepsvennootschappen in concernverband, ook wanneer zij niet actief het dagelijks beleid voeren. Het gaat immers om de mogelijkheid die voor een moedervennootschap bestaat om in te grijpen. ${ }^{16}$ Het ontstaansmoment van de plicht om actief toezicht te houden is afhankelijk van de concernstructuur en hoe daaraan feitelijk uitvoering wordt gegeven.

Een interessante vraag die in dit verband opkomt, is vanaf welk moment deze zorgplicht op de moedervennootschap rust c.q. ontstaat. Dit peilmoment is het moment waarop de moedervennootschap weet of redelijkerwijs behoort te weten dat nieuwe crediteuren van de groepsvennootschap niet meer kunnen worden voldaan. ${ }^{17}$ De Hoge Raad stemt in met het oordeel van het hof dat de exacte bepaling van dit moment arbitrair is en dat om die reden aan de veilige kant (voor de moedervennootschap) dient te worden gebleven. ${ }^{18}$

Voor een moedervennootschap is het goed om te beseffen dat de wijze waarop zij haar concern gestructureerd heeft, een bepalende omstandigheid kan zijn voor aansprakelijkheid uit onrechtmatige daad. Met andere woorden, sluit de moedervennootschap een kredietfaciliteit af ten behoeve van haar concern, dan is dat dus een omstandigheid die wordt meegewogen bij het beoordelen van de mogelijkheid voor de moedervennootschap om in te grijpen als het (financieel) niet goed gaat met haar groepsvennootschap, en de zorgplicht jegens crediteuren die daarmee wordt geactiveerd.

\subsection{Selectief betalen crediteuren}

Aansprakelijkheid van de moedervennootschap wegens bemoeienis met het beleid van de groepsvennootschap kan zich ook voordoen wanneer de moeder aanstuurt op het selectief betalen van crediteuren van de groepsvennootschap. Een voorbeeld hiervan is het arrest Coral/Stalt. ${ }^{19}$ In dit arrest staat centraal dat de moedervennootschap het liet gebeuren dat de groepsvennootschap een overeenkomst aanging met een crediteur waarvan duidelijk was (voor de moedervennootschap) dat

15. Zie voor alle omstandigheden HR 21 december 2001, ECLI:NL:HR: 2001:AD4499, NJ 2005/96 m.nt. Kortmann (Sobi/Hurks II), r.o. 3.1 (i $\mathrm{t} / \mathrm{m}$ vii).

16. Lennarts 2010, p. 189.

17. I. Wassenaar, Noodlijdende dochters en aansprakelijkheid van hun moeders, TOP 2007, afl. 4, p. 176.

18. HR 21 december 2001, ECLI:NL:HR:2001:AD4499, NJ 2005/96 m.nt. Kortmann (Sobi/Hurks II), r.o. 4.2.5 en 5.3.5.

19. HR 12 juni 1998, ECLI:NL:HR:1998:ZC2669, NJ 1998/727 m.nt. Van Schilfgaarde (Coral/Stalt). 


\section{Maandblad}

Ondernemingsrecht

de groepsvennootschap die niet na zou kunnen komen. De moedervennootschap heeft vervolgens de activiteiten van de groepsvennootschap stopgezet en het nog resterende vermogen van de groepsvennootschap gebruikt ter voldoening van intercompany-vorderingen. ${ }^{20}$

De Hoge Raad overweegt dat niet de regel kan worden aanvaard dat een groepsvennootschap die bij beëindiging van haar bedrijfsactiviteiten niet al haar schuldeisers kan voldoen, de vrijheid zou hebben om de tot haar groep behorende crediteuren steeds met voorrang te voldoen boven de niet tot haar groep behorende crediteuren. ${ }^{21}$ Dit heeft voor de moedervennootschap die betrokken was bij de beëindiging van de bedrijfsactiviteiten tot gevolg dat op haar de zelfstandige zorgvuldigheidsplicht rust om toe te zien op een gelijke behandeling van de crediteuren. ${ }^{22}$ Het is de combinatie van de intensieve beleidsbemoeienis van de moedervennootschap en de betrokkenheid bij de afwikkeling van de bedrijfsactiviteiten (waaronder ook het in de hand werken van de ongelijke behandeling van crediteuren), wat in het onderhavige geval heeft geleid tot een schending van de zorgplicht en daarmee een onrechtmatige daad jegens de benadeelde crediteur. ${ }^{23}$

\subsection{Ongeoorloofd vermogen onttrekken aan groepsvennootschap}

De derde wijze waarop een moedervennootschap zich onrechtmatig met het beleid van haar groepsvennootschap kan bemoeien, is door het beleid van de groepsvennootschap zodanig te beïnvloeden dat zij op ongeoorloofde wijze vermogen onttrekt aan de groepsvennootschap. Deze situatie komt aan bod in het arrest Nimox. ${ }^{24}$ De moedervennootschap had zich in dat arrest nagenoeg het hele vermogen van haar groepsvennootschap in de vorm van een dividend laten uitbetalen. Vervolgens leent zij dit bedrag aan de groepsvennootschap. Enige tijd later failleert de groepsvennootschap. Maeijer merkt in zijn noot bij het arrest op dat de moeder in het faillissement een concurrente vordering uit hoofde van de lening heeft, in plaats van een achtergestelde vordering als residual claimant ${ }^{25}$ De Hoge Raad heeft geoordeeld dat een besluit tot dividenduitkering door de moedervennootschap in haar hoedanigheid als aandeelhouder onrechtmatig kan zijn tegenover crediteuren van de groepsvennootschap, indien de moedervennootschap er ernstig rekening mee had moeten houden dat door de uitkering een tekort bij de groepsvennootschap zou ontstaan en crediteuren daardoor benadeeld zouden

20. HR 12 juni 1998, ECLI:NL:HR:1998:ZC2669, NJ 1998/727 m.nt. Van Schilfgaarde (Coral/Stalt), r.o. 1.2; A.E.H. van der Voort Maarschalk, Aansprakelijkheid moedermaatschappij voor haar dochter, O\&F 2002/54, p. 56

21. HR 12 juni 1998, ECLI:NL:HR:1998:ZC2669, NJ 1998/727 m.nt. Van Schilfgaarde (Coral/Stalt), r.o. 3.4.3.

22. HR 12 juni 1998, ECLI:NL:HR:1998:ZC2669, NJ 1998/727 m.nt. Van Schilfgaarde (Coral/Stalt), r.o. 3.5.

23. Van Liere 2015, p. 51.

24. HR 8 november 1991, ECLI:NL:HR:1991:ZC0401, NJ 1992/174 m.nt. Maeijer (Nimox).

25. Zie Maeijer in zijn noot (par. 5) bij HR 8 november 1991, ECLI:NL:HR:1991:ZC0401, NJ 1992/174 (Nimox). worden. ${ }^{26}$ Het gaat er in dit arrest dus om dat een moedervennootschap onrechtmatig kan handelen jegens crediteuren van haar groepsvennootschap als zij zichzelf promoveert als schuldeiser en daarmee de rangorde doorbreekt.

\section{Scheppen van onjuiste verwachtingen bij crediteuren van de groepsvennootschap}

De tweede categorie van gedragingen die tot aansprakelijkheid van de moedervennootschap op grond van onrechtmatige daad kan leiden, is het scheppen van onjuiste verwachtingen door de moedervennootschap bij de crediteuren van de groepsvennootschap. De moedervennootschap kan dergelijke verwachtingen scheppen door bij crediteuren van de noodlijdende groepsvennootschap de indruk te wekken dat laatstgenoemde kredietwaardig is. ${ }^{27}$ Een andere mogelijkheid is dat de moedervennootschap een bepaald vertrouwen wekt bij een crediteur van de groepsvennootschap middels een geruststellende toezegging en dit vertrouwen vervolgens niet honoreert. ${ }^{28}$ Hoewel hierbij nog steeds sprake is van onvrijwillige aansprakelijkheid - de moedervennootschap verklaart zichzelf immers (meestal) niet aansprakelijk, zoals bijvoorbeeld bij een 403-verklaring het geval is -, dient te worden genuanceerd dat de moedervennootschap met het doen van toezeggingen wel degelijk haar aansprakelijkheidsrisico vergroot.

\subsection{Wekken schijn van kredietwaardigheid}

In Albada Jelgersma II gaat het om de situatie dat de moedervennootschap de aandelen in een vennootschap koopt die daarmee als het ware door haar moeder in het concern als dochter wordt geadopteerd. Deze groepsvennootschap verkeert ten tijde van de aankoop in financiële moeilijkheden. $\mathrm{Na}$ de verwerving van de aandelen in deze groepsvennootschap heeft de moeder zich intensief bemoeid met het beleid - en de poging tot herstel - van de groepsvennootschap. ${ }^{29}$ Een relevante omstandigheid is dat de moeder veel uitlatingen in het publiek domein had gedaan, op basis waarvan de indruk was gewekt bij crediteuren van de groepsvennootschap dat de moeder er gaandeweg in zou slagen de groepsvennootschap weer financieel gezond te krijgen. ${ }^{30}$ De moeder is voorts aansprakelijk op grond van onrechtmatige daad voor de facturen die onbetaald zijn gebleven, nadat voor de moeder - op basis van een accountantsrapport - duidelijk is geworden dat de groepsvennootschap geen nieuwe verbintenissen na zou kunnen komen. De moedervennootschap wist immers dat de groepsvennootschap haar verbintenissen niet meer na kan komen en toch laat zij de groepsvennootschap nieuwe verbintenissen aangaan, waarna de facturen onbetaald blijven.

26. Wassenaar 2007, p. 175; HR 8 november 1991, ECLI:NL:HR 1991:ZC0401, NJ 1992/174 m.nt. Maeijer (Nimox), r.o. 3.3.3.

27. HR 19 februari 1988, ECLI:NL:HR:1988:AG5761, NJ 1988/487 m.nt Van der Grinten (Albada Jelgersma II); HR 25 september 1981, ECLI:NL:HR:1981:AG4232, NJ 1982/443 m.nt. Maeijer (Osby).

28. HR 18 november 1994, ECLI:NL:HR:1994:ZC1544, NJ 1995/170 m.nt. Maeijer (NBM/Securicor).

29. Van der Voort Maarschalk 2002, p. 55.

30. HR 19 februari 1988, ECLI:NL:HR:1988:AG5761, NJ 1988/487 m.nt Van der Grinten (Albada Jelgersma II), r.o. 3.3. 
Deze situatie kan worden gecontrasteerd met de situatie in Albada Jelgersma I. ${ }^{31}$ Daar betrof het geen uitlatingen erga omnes, maar brieven van de moedervennootschap (Albada Jelgersma) aan specifieke crediteuren. Dit leidde voor crediteuren van de groepsvennootschap van Albada Jelgersma tot een contractuele vordering op Albada Jelgersma, op grond waarvan zij verhaal konden nemen op de moedervennootschap voor alle onbetaald gebleven facturen. De omvang van de aansprakelijkheid is dus groter in Albada Jelgersma I dan in Albada Jelgersma II.

Vergelijkbare problematiek staat centraal in het arrest Osby. ${ }^{32}$ De moedervennootschap heeft een lening verstrekt aan haar noodlijdende groepsvennootschap in ruil voor een fiduciaire zekerheidsoverdracht van nagenoeg alle activa van de groepsvennootschap. Dit had tot gevolg dat een crediteur van de groepsvennootschap zich in het faillissement van de groepsvennootschap niet op de groepsvennootschap kon verhalen.

In de hiervoor besproken arresten kunnen omstandigheden worden gevonden op basis waarvan bepaald kan worden of de moeder aansprakelijk is voor het wekken van een schijn van kredietwaardigheid. Ten eerste zal moeten worden aangetoond dat de moeder een schijn van kredietwaardigheid heeft gewekt (bijvoorbeeld door kredietverschaffing). Voorts is vereist dat de moeder objectieve wetenschap had van de benadeling van de crediteur en dat de moeder ook heeft nagelaten de crediteur te waarschuwen. ${ }^{33}$

\subsection{Niet nakomen toezeggingen en schenden gerechtvaardigd vertrouwen}

De moedervennootschap kan ook aansprakelijk zijn voor schulden van haar groepsvennootschap wanneer zij het vertrouwen wekt bij crediteuren van de groepsvennootschap dat deze schulden ook zullen worden voldaan (al dan niet door de moedervennootschap zelf). In dat kader kan ook gedacht worden aan een patronaatsverklaring c.q. letter of comfort die de moeder richt aan een specifieke crediteur, waarbij een contractuele band gecreëerd kan worden. ${ }^{34}$ In deze bijdrage gaat het echter om algemene(re) uitlatingen erga omnes in het publiek domein en niet jegens een specifieke schuldeiser. ${ }^{35}$

In NBM/Securicor heeft de moedervennootschap, in haar hoedanigheid van enig aandeelhouder en bestuurder van de groepsvennootschap, mededelingen gedaan waaraan de crediteur het vertrouwen mocht ontlenen dat zijn vordering zou

31. HR 13 september 1985, ECLI:NL:HR:1985:AC3181, NJ 1987/98 m.nt. C.J.H. Brunner.

32. HR 25 september 1981, ECLI:NL:HR:1981:AG4232, NJ 1982/443 m.nt. Maeijer (Osby).

33. Zie ook Wassenaar 2007, p. 175.

34. Zie over de contractuele band en patronaatsverklaring L. Leber, De patronaatsverklaring, Deventer: Wolters Kluwer 2017, par. 5.3.3.1.

35. Zie voor het verschil in soort uitlating en het gevolg daarvan voor de omvang van de aansprakelijkheid ook de hiervoor in par. 3.1 besproken arresten Albada Jelgersma I en Albada Jelgersma II. worden voldaan ${ }^{36}$ en de moedervennootschap de belangen van crediteuren van haar groepsvennootschap zou behartigen. ${ }^{37}$ De Hoge Raad oordeelt dat de moedervennootschap aansprakelijk is voor haar onrechtmatig handelen jegens de crediteur, doordat zij het bij de crediteur gewekte vertrouwen niet honoreert en de factuur van de crediteur onbetaald blijft. ${ }^{38}$ Maeijer merkt in zijn noot bij dit arrest op dat het in het onderhavige geval gaat om het opgewekte vertrouwen bij een bepaalde crediteur. Dit is specifieker dan het wekken van een schijn van kredietwaardigheid tegenover crediteuren in het algemeen, zoals hierboven is besproken met betrekking tot Albada Jelgersma II, hetgeen tot gevolg heeft dat een bepaalde crediteur bij wie vertrouwen is gewekt, erop mag vertrouwen dat hij door de moedervennootschap zal worden betaald. ${ }^{39}$

\section{Samenvatting omstandigheden die leiden tot onvrijwillige aansprakelijkheid van moedervennootschap}

Op basis van de verschillende hiervoor besproken casus kan een stappenplan worden gevormd voor de beantwoording van de vraag of de moedervennootschap aansprakelijk is op grond van onrechtmatige daad: ${ }^{40}$

- Eerst dient te worden bepaald welke mate van verbondenheid de concernstructuur kent en het gemak waarmee de moedervennootschap had kunnen ingrijpen.

- Voorts dient te worden vastgesteld welke zorgplicht de moedervennootschap jegens crediteuren heeft, mede in het licht van de concernstructuur en de mate van beleidsbemoeienis.

- Daarna dient het peilmoment te worden bepaald. Dit is het moment waarop de moeder op de hoogte was of had moeten zijn van de slechte toestand van haar groepsvennootschap, en dit is daarmee tevens het moment waarop de zorgplicht geactiveerd wordt. ${ }^{41}$

- Tot slot dient dan te worden vastgesteld of de moedervennootschap aan deze zorgplicht heeft voldaan. De moedervennootschap is aansprakelijk wanneer blijkt dat zij deze zorgplicht heeft geschonden.

36. Het vertrouwen was - door moedervennootschap NBM - gewekt dat de groepsvennootschap in staat zou zijn haar financiële verplichtingen jegens crediteur Securicor na te komen, althans door NBM daartoe in staat gesteld zou worden.

37. HR 18 november 1994, ECLI:NL:HR:1994:ZC1544, NJ 1995/170 m.nt Maeijer (NBM/Securicor), r.o. 3.2.

38. HR 18 november 1994, ECLI:NL:HR:1994:ZC1544, NJ 1995/170 m.nt Maeijer (NBM/Securicor), r.o. 3.4.

39. Maeijer in zijn noot (par. 3) bij HR 18 november 1994, ECLI:NL:HR: 1994:ZC1544, NJ 1995/170 (NBM/Securicor). Zie voor het verschil in de omvang van aansprakelijkheid bij uitlatingen erga omnes en jegens specifieke crediteuren ook de bespreking van Albada Jelgersma I en II in par. 3.1.

40. Zie ook Bartman, Dorresteijn \& Olaerts 2016, p. 265; H.M. Cornelissen, L.N.M. van Uden \& E.M. Hoogervorst, Parental liability, in: E.M. Hoogervorst e.a. (red.), Kartelschade (O\&R nr. 108), Deventer: Wolters Kluwer 2019, p. 57-58.

41. Zie par. 2.1 en HR 21 december 2001, ECLI:NL:HR:2001:AD4499, NJ 2005/96 m.nt. Kortmann (Sobi/Hurks II), r.o. 5.3.5. 


\section{Maandblad}

Ondernemingsrecht

Het vorenstaande stappenplan past vooral bij de hiervoor in paragraaf 2 geïdentificeerde risico's met betrekking tot de beleidsbemoeienis van de moedervennootschap. Niettemin kan het stappenplan ook toepassing vinden op situaties besproken in paragraaf 3 . Bij de eerste stap is dan ook van belang welke mate van inzicht de moedervennootschap heeft in de situatie bij de groepsvennootschap. Bij de tweede stap zal moeten worden gekeken of de moedervennootschap een schijn van kredietwaardigheid heeft gewekt en objectieve wetenschap had van benadeling. Als blijkt dat daaraan voldaan is en de moedervennootschap haar zorgplicht jegens crediteuren van de groepsvennootschap heeft geschonden, volgt evenwel aansprakelijkheid van de moedervennootschap. Voor beide aansprakelijkheidscategorieën geldt dat wanneer de aansprakelijkheid van de moedervennootschap vaststaat, de te vergoeden schade door de moeder bepaald dient te worden. Deze kan verschillen van de omvang van de vordering die de schuldeiser jegens de dochter heeft en hangt af van de omstandigheden van het geval. Het gaat namelijk om een eigen onrechtmatige daad van de moeder. ${ }^{42} \mathrm{Bij}$ directe doorbraak c.q. vereenzelviging is de omvang van de aansprakelijkheid gelijk aan het bedrag van de vordering; er wordt immers aan het identiteitsverschil tussen beide rechtspersonen voorbijgegaan. ${ }^{43}$

\section{Suggesties ter beperking van het risico op onvrijwillige aansprakelijkheid van de moedervennootschap}

In het vorenstaande ging het om de omstandigheden die ertoe kunnen leiden dat de moeder een zorgplicht in acht heeft te nemen jegens crediteuren van haar groepsvennootschap en dat een schending van die zorgplicht tot aansprakelijkheid op grond van onrechtmatige daad kan leiden. Zoals duidelijk is geworden, zijn er veel soorten gedragingen die tot aansprakelijkheid van de moedervennootschap kunnen leiden. Daarom bespreek ik hierna enkele suggesties voor een moedervennootschap om de aansprakelijkheidsrisico's te beperken. Zoals eerder opgemerkt, kunnen deze suggesties negatieve gevolgen hebben vanuit het oogpunt van concernleiding. Of het beperken van het aansprakelijkheidsrisico zwaarder weegt dan de voordelen van een nauw concernverband (in (bedrijfs)economische, organisatorische en juridische zin), is een afweging die ieder concern zelf zal moeten maken.

\subsection{Beperking van beleidsbemoeienis en minder hechte concernstructuur}

Zoals is gebleken uit de bespreking van de verschillende arresten hierboven, is een belangrijke voorwaarde voor aansprakelijkheid van de moedervennootschap dat zij zich (te) indringend bemoeid heeft met het beleid van de groepsvennootschap, dan wel dat de concernstructuur zodanig was dat de moedervennootschap voldoende invloed had kunnen uitoefenen ter voorkoming van de benadeling van de crediteur.

42. Cornelissen, Van Uden \& Hoogervorst 2019, par. 3.3.

43. HR 13 oktober 2000, ECLI:NL:HR:2000:AA7480, NJ 2000/698 m.nt. Maeijer (Rainbow/Ontvanger); Asser/Maeijer, Van Solinge \& Nieuwe Weme 2-II* 2009/835.
Makkelijk en voor de hand liggend is het om de suggestie te doen dat de moedervennootschap simpelweg beter op haar gedragingen let. Toch zou dit onvoldoende zijn, het biedt immers geen garantie dat de moedervennootschap niet alsnog een zorgplicht heeft en schendt jegens schuldeisers van de groepsvennootschap. Beter is het daarom om naar een structurele oplossing te zoeken. Ik stel hierna twee van dergelijke oplossingen voor.

\subsubsection{Instructiemacht}

De eerste voorzorgsmaatregel ziet op de instructiemacht van (de bestuurders van) de moedervennootschap ten aanzien van de groepsvennootschap. Hoewel het bestuur van een vennootschap - en dus ook een groepsvennootschap - in beginsel op grond van artikel 2:129/239 lid $1 \mathrm{BW}$ zelfstandig belast is met het besturen van de vennootschap, wordt in de literatuur vaak de AV als hoogste macht aangeduid vanwege de belangrijke bevoegdheden die haar toekomen. ${ }^{44}$ Er bestaat dan ook spanning tussen de beleidsvrijheid van het bestuur enerzijds en de instructiemacht van de $\mathrm{AV}$ anderzijds. In concernverband roept dat de vraag op wat de reikwijdte is van de instructiemacht van de moedervennootschap, en - meer specifiek - hoe deze (statutair) beperkt kan worden, opdat minder snel een indringende bemoeienis wordt aangenomen op grond waarvan de moedervennootschap aansprakelijk kan zijn. In ieder geval heeft de AV de bevoegdheid om bestuurders te benoemen, ${ }^{45}$ schorsen en ontslaan. ${ }^{46}$

De instructiemacht van de AV is geregeld in artikel 2:129/239 lid $4 \mathrm{BW}$. Deze bepaling laat het toe dat de statuten van een vennootschap kunnen bepalen dat het bestuur zich dient te gedragen naar instructies van een vennootschapsorgaan. ${ }^{47} \mathrm{Wil}$ een moedervennootschap voorkomen dat haar een (te) intensieve beleidsbemoeienis wordt verweten, dan doet zij er goed aan om geen instructiebevoegdheid in de statuten van de groepsvennootschap op te nemen, om zo een grotere zelfstandigheid van (het beleid van) de groepsvennootschap te creëren. Dit is tevens goed verenigbaar met het oordeel van de Hoge Raad in Sobi/Hurks II 'dat, tenzij de statuten van de dochtermaatschappij daaromtrent enige andersluidende bepaling bevatten, het bestuur van een moedermaatschappij niet de bevoegdheid heeft bindende instructies te geven aan het bestuur van een dochtermaatschappij'. ${ }^{48}$ Vanuit het oogpunt

44. Zie bijv. Asser/Maeijer, Van Solinge \& Nieuwe Weme 2-IIa 2019/20, J.W. Winter, J.B. Wezeman \& J.D.M. Schoonbrood, Van Schilfgaarde. Van de BV en de NV, Deventer: Wolters Kluwer 2017, p. 248 en A.P.M. van der Westerlaken, Instructiemacht in de praktijk, V\&O 2002, afl. 12, p. 209.

45. Art. 2:132/242 lid 1 BW.

46. Art. 2:134/244 BW. Bij structuurvennootschappen is dit anders: dan is de RvC bevoegd, zie art. 2:162/272 BW.

47. Asser/Maeijer, Van Solinge \& Nieuwe Weme 2-IIb 2019/152 e.v.

48. HR 21 december 2001, ECLI:NL:HR:2001:AD4499, NJ 2005/96 m.nt. Kortmann (Sobi/Hurks II), r.o. 5.3.8.3. Opmerking verdient dat de Hoge Raad verder overweegt dat het om de feitelijke instructiemacht gaat. Of de voorgestelde papieren werkelijkheid in de statuten voldoende is, moet worden bezien. Zie ook Asser/Maeijer, Van Solinge \& Nieuwe Weme 2-IIb 2019/157 e.v. 
van concernleiding kan het ongunstig zijn om op grotere afstand van de groepsvennootschap te staan. Ook dient bij deze maatregel de vraag te worden gesteld in hoeverre de papieren werkelijkheid in de statuten voldoende is om het aansprakelijkheidsrisico te beperken.

\subsubsection{Concernstructuur - oprichten administratiekantoor}

Een tweede voorzorgsmaatregel voor de moedervennootschap om meer afstand te creëren tussen haar en de groepsvennootschap, is het oprichten van een stichting administratiekantoor (STAK). De aandelen van de moedervennootschap in de groepsvennootschap worden dan ten titel van beheer overgedragen aan het administratiekantoor. Voorts geeft het administratiekantoor certificaten van aandelen uit aan de moedervennootschap (de oorspronkelijke aandeelhouder). ${ }^{49}$ De moeder 'degradeert' derhalve van aandeelhouder naar certificaathouder. Prima facie lijkt dit misschien niet in het belang van de moeder, maar deze nieuwe situatie heeft een belangrijk voordeel in het kader van doorbraak van aansprakelijkheid. Door certificering van de aandelen - en dus ook de overdracht van de aandelen aan het administratiekantoor - is het administratiekantoor aandeelhouder geworden en de goederenrechtelijk rechthebbende tot de aandelen. In die hoedanigheid kan het administratiekantoor het stemrecht op de aandelen uitoefenen. ${ }^{50}$ Dit betekent dat er een (in ieder geval op papier) onafhankelijk bestuur zit tussen de moedervennootschap en de groepsvennootschap, waardoor de moedervennootschap minder snel een indringende bemoeienis en/of invloed op het beleid van de groepsvennootschap kan worden verweten. ${ }^{51}$ Opmerking verdient dat de moedervennootschap er goed aan doet om in de administratievoorwaarden die de verbintenisrechtelijke verhouding tussen de moedervennootschap en het administratiekantoor regelt, op te nemen dat decertificering van aandelen mogelijk is, mocht zij op enig moment besluiten zelf weer aandeelhouder te willen zijn. Verder wordt in artikel 2:118a BW bepaald dat een certificaathouder (lees: de moedervennootschap) kan verzoeken dat zij door de STAK wordt gevolmachtigd om het stemrecht op de aandelen uit te oefenen.

\subsection{Geen onjuiste verwachtingen en vertrouwen wekken}

Voor wat betreft het wekken van onjuiste verwachtingen en vertrouwen gaat het primair om uitlatingen van de moedervennootschap (gedaan door haar bestuurders), waarop de crediteur van de groepsvennootschap gerechtvaardigd vertrouwt. Waar de voorgaande suggesties werden gezocht in aanpassingen van de concernstructuur, zal de oplossing voor dit risico in de sfeer van beleidsveranderingen bij de moedervennootschap liggen. Zo zullen bestuurders van de moedervennootschap zo min mogelijk uitlatingen moeten doen over groepsvennootschappen en moeten deze uitlatingen niet te concreet zijn, na

49. Van Schilfgaarde/Winter, Wezeman \& Schoonbrood 2017, p. 65.

50. Art. 2:118/228 lid $1 \mathrm{BW}$.

51. Hierbij dient de kanttekening te worden geplaatst dat dit bestuur in de praktijk beperkt onafhankelijk zal zijn, mede omdat de concernleiding ook niet zal willen dat de STAK ondernemingsbeslissingen gaat nemen. het peilmoment. Hierbij verdient opmerking dat indien de moedervennootschap geen enkele vertrouwenwekkende uitlating doet, dit er waarschijnlijk toe leidt dat leveranciers niet meer bereid zijn te leveren aan de groepsvennootschap. Er zal dus een balans moeten worden gevonden.

Verder kan eraan worden gedacht om een aparte vertegenwoordiger per vennootschap in het concern aan te stellen. Uitsluitend deze vertegenwoordiger is bevoegd om uitlatingen over vennootschappen in het concern te doen. ${ }^{52}$ De moedervennootschap en haar bestuurders kan dan minder makkelijk worden verweten bepaalde verwachtingen of vertrouwen gewekt te hebben bij crediteuren van een groepsvennootschap, want die verwachtingen zijn gewekt door een vertegenwoordiger van de groepsvennootschap. Of dergelijke vertrouwenwekkende uitlatingen even succesvol zijn in het wekken van vertrouwen bij crediteuren als een uitlating van de moedervennootschap, zal moeten worden bezien. Bovendien kan het soms noodzakelijk zijn om positieve uitlatingen te doen over de groepsvennootschap, in een laatste poging de onderneming draaiende te houden.

\section{Conclusie}

In deze bijdrage is de onvrijwillige aansprakelijkheid van de moedervennootschap op grond van een eigen onrechtmatige daad jegens de crediteuren van de groepsvennootschap besproken. Gedragingen van een moedervennootschap die onrechtmatig kunnen zijn in de zin van artikel 6:162 BW heb ik verdeeld in twee categorieën: enerzijds beleidsbemoeienis en anderzijds het scheppen van onjuiste verwachtingen bij crediteuren van de groepsvennootschap. De zorgplicht voor de moedervennootschap kan zijn grondslag vinden in een hechte concernstructuur (wat ingrijpen bij de groepsvennootschap mogelijk makkt) en een intensieve en indringende beleidsbemoeienis. Het moment waarop deze zorgplicht wordt geactiveerd, is door de Hoge Raad in Sobi/Hurks II gedefinieerd als het moment waarop de moedervennootschap weet of redelijkerwijs behoort te weten dat nieuwe crediteuren van de groepsvennootschap niet meer zullen kunnen worden voldaan.

Ter voorkoming van een (te) hechte concernstructuur en intensieve beleidsbemoeienis, althans een vermoeden daarvan, heb ik enkele suggesties gedaan. Zo kan in de statuten van de groepsvennootschap geen instructiemacht aan de moedervennootschap worden toegekend, waardoor de moedervennootschap minder snel een verwijt treft dat zij schade bij de crediteuren heeft veroorzaakt, dan wel dat zij had moeten en kunnen ingrijpen bij haar groepsvennootschap. Een (vermoeden van een) (te) hechte concernstructuur kan worden voor-

52. Hoewel het risico bestaat dat dergelijke uitlatingen van een vertegenwoordiger aan de rechtspersoon kunnen worden toegerekend op grond van het Kleuterschool Babbel-arrest (HR 6 april 1979, ECLI:NL:HR: 1979:AH8595, NJ 1980/34 m.nt. C.J.H. Brunner), zal deze rechtspersoon in beginsel de groepsvennootschap zijn en niet de moedervennootschap. 


\section{Maandblad}

Ondernemingsrecht

komen middels certificering van aandelen en de oprichting van een STAK. Het administratiekantoor heeft een onafhankelijk bestuur en oefent het stemrecht uit namens de certificaathouders c.q. de moedervennootschap. Hierdoor ontstaat een grotere afstand tussen de moedervennootschap en de groepsvennootschap in de concernstructuur. Tot slot heb ik gewezen op het voorkomen van het wekken van gerechtvaardigd vertrouwen en verwachtingen bij crediteuren van de groepsvennootschap. Dit kan worden bereikt door in het bestuursreglement van de moedervennootschap op te nemen dat haar bestuurders geen (te concrete) uitlatingen doen over een groepsvennootschap, en door een vertegenwoordiger te benoemen per vennootschap in het concern. In hoeverre deze maatregelen ter beperking van het aansprakelijkheidsrisico van de moedervennootschap opwegen tegen de beperkingen die zij met zich brengen vanuit het oogpunt van concernleiding, is een afweging die elk concern zelf zal moeten maken. 